\title{
Straw Mulching with Minimum Tillage Is the Best Method Suitable for Straw Application under Mechanical Grain Harvesting
}

\author{
En Lei, ${ }^{1,2}$ ChaoBo Wang, ${ }^{2}$ Wen Xue Li, ${ }^{2}$ Yue Dong Wang, ${ }^{3}$ Yong Bing Yang, ${ }^{3}$ Hua Bin Zheng, \\ and Qi Yuan Tang ${ }^{1}$
}

${ }^{1}$ College of Agronomy, Hunan Agricultural University, Hunan, Changsha 410128, China

${ }^{2}$ College of Biological and Agricultural Sciences, Honghe University, Mengzi, Yunnan, 661100, China

${ }^{3}$ Agricultural Maechinery Research Institute of Yunnan Honghe Hani and Yi Autonomous Prefecture, Mengzi,

Yunnan 661100, China

Correspondence should be addressed to Qi Yuan Tang; tlf3300@hunau.edu.cn

Received 28 October 2021; Revised 25 November 2021; Accepted 9 December 2021; Published 26 December 2021

Academic Editor: Bai Yuan Ding

Copyright (C) 2021 En Lei et al. This is an open access article distributed under the Creative Commons Attribution License, which permits unrestricted use, distribution, and reproduction in any medium, provided the original work is properly cited.

\begin{abstract}
Mechanical grain harvesting is a crop production development direction. However, the residue management methods suitable for mechanical grain harvesting have been not established. In order to study the effect of residue management modes on maize yield formation and explore the best residue management methods for mechanical grain harvesting, four crop field surveys were carried out in Southwest China. Crops were mechanically harvested, and the residues were shredded and returned to the field using various straw application methods including straw deep burial with plowing (SDBP), straw shallow burial with rotary tillage (SSBRT), and straw mulching with minimum tillage (SMMT). The first-season rape residues were returned to the field, and the second-season maize yield under SDBP and SSBRT was significantly higher than that under SMMT. However, with the increase in rounds of residue application, compared with SDBP and SSBRT, SMMT continuously increased the soil moisture content in the $0-30 \mathrm{~cm}$ soil layer at the early stage of maize growth, increased the soil alkaline-hydrolyzed nitrogen content in the $0-20 \mathrm{~cm}$ and 40-60 cm layers, and reduced the soil compaction under $40 \mathrm{~cm}$ layer, which were more conducive to the root system growth. Maize yield with the SMMT increased by $5.4 \%$ compared with that of the previous season, while the yields with SDBP and SSBRT decreased by $16.7 \%$ and $12.7 \%$, respectively, compared with those of the previous season. In conclusion, it is recommended to employ the SMMT method during crop mechanical harvesting, which is of great significance to improve soil quality and increase maize grain yield.
\end{abstract}

\section{Introduction}

Previous studies have pointed out that the long-term application of conventional farming methods and removing crop residues have severely disturbed and destroyed the natural structure of the soil, resulting to a continuous decline in the soil organic matter content, which restricts the increase of crop grain yield [1]. As a potential bioenergy, the crop residues after harvesting can be returned to the fields to combine with soil tillage. Straw application can improve soil tilth and fertility, maintain soil productivity, and increase crop grain yield [2]. Straw returns could continuously increase soil organic carbon in an interannual rotation cropping system [3].
Some studies have shown that continuous straw application significantly reduced the soil bulk density from the 4th year [4], which greatly improved the stability of soil aggregates [5]. Straw application can regulate soil moisture content and temperature, affect the vertical distribution of soil available nitrogen [6], and reduce ammonia volatilization from soils [7]. With straw application, the alkalinehydrolyzed nitrogen $(\mathrm{AH}-\mathrm{N})$ content of the soil increased by $6 \%-14 \%$ and $8 \%-34 \%$, respectively, compared to that of soils without crop residues [8]. After straw application for six consecutive years, the soil organic carbon and available nitrogen contents in each soil aggregate-size class increased by $27 \%$ and $12 \%$, respectively [2], compared with those of 
soils without crop residues. In addition, straw application significantly reduced the soil penetration resistance, leading to a 1.4-fold increase in water infiltration rate of the soil [9]. This effect is most significant in areas where the soils are of poor fertility [10]. Straw application can also increase the organic matter content and the accumulation of humus components in the soil, improve the structure of soil humus [11], increase the abundance of soil microbiota [5], and facilitate the activities of soil dehydrogenase and phosphatase $[4,12]$. Straw returns improved the fertilizer effects on soil bulk density, soil porosity, maize root length, root surface area, root volume, and yield by $3.99 \%-7.27 \%, 3.89 \%-$ $7.40 \%, 1.35 \%-71.01 \%, 19.16 \%-42.45 \%, 10.49 \%-22.73 \%$, and $4.43 \%-7.05 \%$, respectively [13]. Therefore, straw application is conducive to increase crop grain yield, nitrogen use efficiency [14], and economic benefit [15].

However, the undecomposed crop residues will hinder the emergence [16] and growth [17] of the crop in the coming season. Therefore, in areas with multiple cropping systems, additional nitrogen fertilizers are applied every year after straw application to promote the decomposition of crop residues $[18,19]$. Straw application promotes the accumulation of nutrients in the surface soil layers; however, its effect on increasing crop grain yield is related to factors such as soil types [20] and soil tillage methods [21]. Soil tillage methods significantly influence the accumulation and transformation of nutrients in the soil [22]. A previous study has demonstrated that the plowing tillage technology during straw application can increase the organic carbon and total nitrogen contents of the surface soil layers, thereby increasing the maize grain yield and water use efficiency [23]. Other studies have shown that the carbon content of organic matter, humus, humic acid, and fulvic acid [11], as well as the total nitrogen release in the soil are significantly higher using the shallow burial method than those with deep burial treatment [24]. Straw shallow burial can significantly increase the degradation rate of straws, which may be related to the increase in the catabolic versatility of the soil microbiota [25] and the decrease in the ratio of $\mathrm{G}^{+} / \mathrm{G}^{-}$ bacteria [26]. Compared with the straw deep burial, the comprehensive indices of soil nutrients can reach their maximums with the shallow burial method [27]. However, soil moisture content and temperature tend to decrease significantly whether using the deep burial with plowing tillage method or shallow burial method, which lead to a decrease in the emergence rate of the crop in the coming season [28].

In rain-fed arid areas, straw mulching with minimum tillage can significantly increase the organic carbon content [22], moisture content, and permeability [29] of the $0-100 \mathrm{~cm}$ soil layer, thereby increasing the crop grain yield and soil quality. However, in areas with irrigation systems, this method reduced the soil temperature and thus did not contribute to crop grain yield increase [30]. In other words, the effects of straw application with different soil tillage methods are significantly different among different regions.

In recent years, mechanical grain harvesting has continued to develop in the main maize-producing areas in China. Based on the limitation of harvesting machinery, when grain is harvested by machinery, the straw is crushed by the harvester and returned to the field. However, there was little research about the straw application under mechanical grain harvesting. The results of previous studies were mostly obtained under the condition of manual harvesting. Compared with the traditional way of artificial harvesting and straw recycling, crop residues are simultaneously shredded and returned to the field during mechanical grain harvesting, which poses new demand for studying straw application methods. This is also the challenge and superiority of the analysis program compared with previous studies.

In this study, we conducted field experiments in the red soil area of the Yunnan Plateau, which is the maize and rape double-cropping system production region in Southwest China. We investigated the influences of the straw application in combination with different soil tillage methods on soil tilth and maize grain yield and determined the most appropriate straw application method under mechanical grain harvesting. The findings from this study provide a theoretical basis and technical approach for improving the soil quality and increasing the maize grain yield.

\section{Materials and Methods}

2.1. Experimental Field. The field test was conducted between 2016 and 2018 in Jiale Village at the Town of Jinma, Honghe Hani and Yi Autonomous Prefecture, Yunnan Province, China $\left(24^{\circ} 46^{\prime} \mathrm{N}, 103^{\circ} 30^{\prime} \mathrm{E}\right)$. The region is located at a typical production area of the maize and rape doublecropping system. The field has an altitude of $1,800 \mathrm{~m}$, a subtropical monsoon climate, an annual average temperature of $15.2^{\circ} \mathrm{C}$, and an annual precipitation of $979.7 \mathrm{~mm}$. The soil type is red soil, with adoption of rain-fed farming and rotary tillage practices.

2.2. Straw Application Methods. The split plot experimentation scheme was adopted, maize cultivar was the main plot factor, and straw application was the subplot factor. Jinyu 99 (JY99), an early-maturing maize cultivar, and Baoyu 9 (BY9), a late-maturing maize cultivar, were used for cultivation. All mechanically harvested straw was shredded and applied to the field. Three straw application methods were used: straw deep burial with plowing (SDBP), straw shallow burial with rotary tillage (SSBRT), and straw mulching with minimum tillage (SMMT). Each experimental treatment was repeated in three blocks, and the experimental field was divided into 18 treatment plots $(50 \mathrm{~m} \times 2.4 \mathrm{~m})$. In each plot, four rows of maize were planted at equal distances, with a total plot area of $2,200 \mathrm{~m}^{2}$. Maize was cultivated alternatively with rape plants (Table 1).

Mechanical grain harvesting was conducted using a harvester (Kubota 4LZ-2.5, PRO688Q) with a semifeed header (Jiajiale 4 YG-4A). Plowing was conducted using a 1LH-438 moldboard plow towed with a tractor (LX1204). Rotary tillage was conducted with a rotary tiller towed with the same type of tractor. The detailed experimental procedure is summarized in Table 1. 
TABLE 1: The experimental procedure and straw application methods.

\begin{tabular}{|c|c|c|c|}
\hline $\begin{array}{l}\text { Season and } \\
\text { crop species }\end{array}$ & Cultivation method & Straw application method & $\begin{array}{c}\text { Cumulative number of straw } \\
\text { applications (CNSA) }\end{array}$ \\
\hline
\end{tabular}

Sowed on 10-25-2016. Mechanical furrowing was conducted at a depth of $8-12 \mathrm{~cm}$. Then, a thin layer of soil was applied. Thinning was conducted at V2 and final thinning at V4 during intertillage and weeding. Fertilizers were applied at $276 \mathrm{~kg} /$ Winter-seeded ha for $\mathrm{N}, 120 \mathrm{~kg} / \mathrm{ha}$ for $\mathrm{P}_{2} \mathrm{O}_{5}$, and $150 \mathrm{~kg} / \mathrm{ha}$ rape plant in for $\mathrm{K}_{2} \mathrm{O}$. Nitrogen fertilizer was given at 2016 sowing, germination, and inflorescence emergence at a ratio of $3: 3: 4$. Phosphorus and potassium fertilizers were applied at sowing. Top dressings were applied to the furrows between two rows. Crop maintenance was conducted according to the standard practice for high-yield crops. Sowed on 4-28-2017 at a density of 67,500 plants/ha. Mechanical furrowing was conducted at a depth of $10-15 \mathrm{~cm}$. The fertilizer was applied at $180 \mathrm{~kg} / \mathrm{ha}$ for $\mathrm{N}$, $112.5 \mathrm{~kg} / \mathrm{ha}$ for $\mathrm{P}_{2} \mathrm{O}_{5}$, and $135 \mathrm{~kg} / \mathrm{ha}$ for $\mathrm{K}_{2} \mathrm{O}$. Nitrogen and potassium fertilizers were given Mechanical grain harvesting was carried Summer- at sowing and inflorescence emergence at a out, and straw was shredded on 10-15seeded maize ratio of 5:5. Phosphorus fertilizer was applied in 2017 at sowing. Fertilizers applied during the period of inflorescence emergence were applied into furrows, and top dressings were applied into deep holes punched between every two crops. Crop maintenance was conducted according to the standard practice for high-yield crops, and each plot was treated the same.

Winter-seeded rape plant in 2017

Sowed on 10-28-2017. The same method as

Summerseeded maize in 2018
Mechanical grain harvesting was carried out, and straw was shredded on 4-20-

2017. SDBP: straw was buried at $30-40 \mathrm{~cm}$ during plowing. Then, rotary tillage was carried out. SSBRT: straw was buried at $15-20 \mathrm{~cm}$ during rotary tillage. SMMT: straw was directly applied to the surface of the soil.
2017. Straw application was carried out as per the three methods of the winterseeded rape plant in 2016 .
Cumulative zero rounds of straw application before the rape plant was sown in 2016 (0 CNSA)

Cumulative one round of straw application before maize was sown in 2017 (1 CNSA) winter-seeded rape plant in 2016.

Mechanical grain harvesting was carried out, and straw was shredded on 4-252018. Straw application was carried out as application before the rape plant per the three methods of winter-seeded was sown in 2017 (2 CNSA) rape plant in 2016 .

Sowed on 5-1-2018. The same method as Mechanical grain harvesting was carried summer-seeded maize in 2017. out on 10-22-2018.
Cumulative three rounds of straw application before maize was sown in 2018 (3 CNSA)
2.3. Soil Samples and Collection. Soil profiles $(120 \times 60 \times 60 \mathrm{~cm})$ and root samples $(45 \times 30 \times 60 \mathrm{~cm})$ were manually collected in the maize ear initiation stage (V12) and silking stage (R1) in representative areas in each plot (Figure 1). Soil penetration resistance and water content were tested outside of the four corners of the profile collection area. The alkaline-hydrolyzed nitrogen (AH-N) content and root volume were tested at each depth range $(0-10,10-20,20-30,30-40,40-50$, and 50-60 cm).

\subsection{Soil Penetration Resistance, Water Content, and AH-N} Content. Soil penetration resistance was tested with a penetrometer (TJSD-750), and water content was tested with a soil moisture sensor (TZS-1K). Then, a soil drill was used to collect soil samples. Four sampling points in the same depth range were mixed. Roots and shedding were discarded. Each sample was sieved with a $0.18 \mathrm{~mm}$ filter. The AH-N content was determined with the alkaline hydrolysis diffusion method.
2.5. Root Volume. A stainless-steel blade was used to collect the three sub-blocks of root samples. Samples were transferred to nylon mesh bags before the soil, and other impurities were washed off. All visible maize roots were collected into Ziplock bags and scanned using a high-resolution scanner (Epson Perfection V700). Images were analyzed with the plant root measurement and analysis system (WinRHIZO Pro-2016). The contour map of the root system was drawn by a type of drawing software (Surfer 8.0). The discrete data of root volume were selected, and the interpolation method in Surfer 8.0 was used to grid the data, the regular grid file was obtained, and then the contour map is drawn.

2.6. Determination of Leaf Area Index, Dry Matter Accumulation, and Chlorophyll Content. For each plot, 4 plant samples were collected in the V12 stage and R1 stage and 10 were collected in the physiological maturity (R6) stage. Organs were separated in each plant. For leaf area indices, 

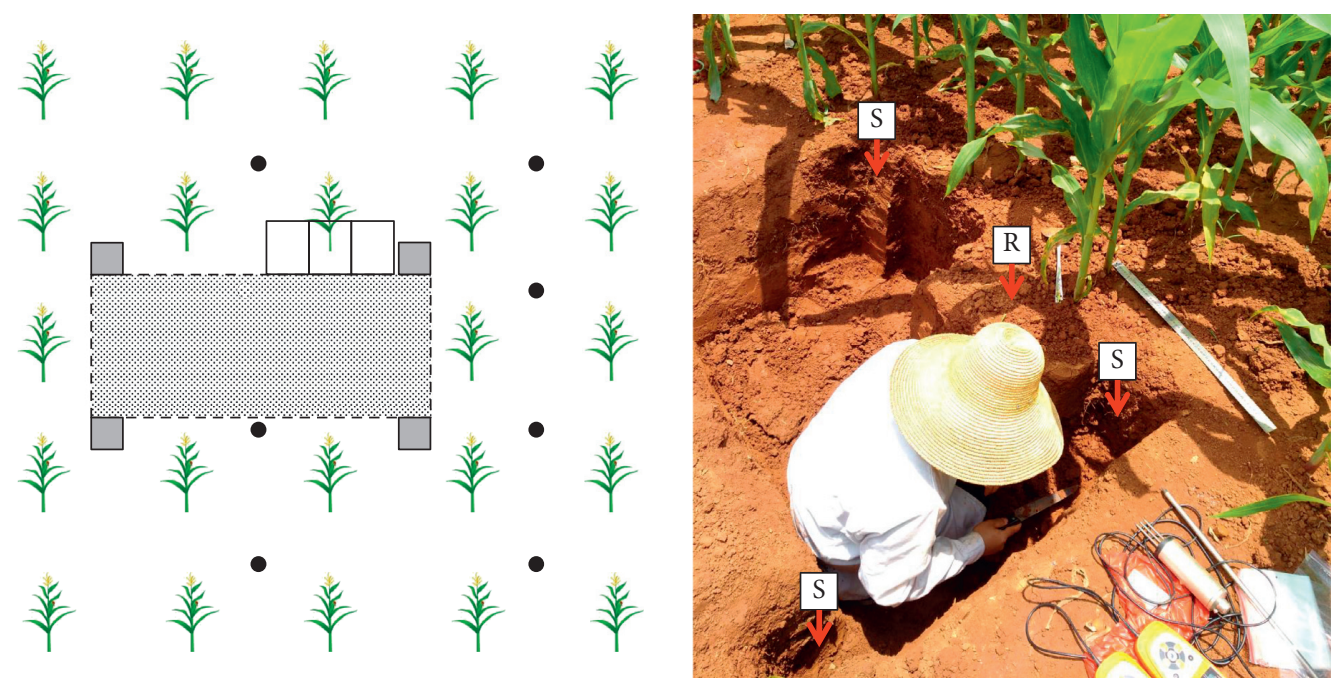

FIgURe 1: Soil samples and collection. maize plant. locations of top-dressing application. soil profile collection region $(120 \times 60 \times 60 \mathrm{~cm})$. sampling points for soil penetration resistance and water content test. maize root sampling area $(45 \times 30 \times 60 \mathrm{~cm})$, including three subblocks at the plant, left to the plant, and right to the plant. Tests on soil and root samples were carried out at 0-10, 10-20, 20-30, 30-40, 40-50, and 50-60 cm in depth. The capital R stands for maize root sampling area and the $S$ stands for soil sampling points.

the lengths and widths of all leaves were measured and the leaf area index was calculated as length $\times$ width $\times$ coefficient, where coefficient $=0.50$ when the leaves were not fully unrolled and 0.75 otherwise. For dry matter accumulation, each sample was baked at $105^{\circ} \mathrm{C}$ and then dried at $75^{\circ} \mathrm{C}$ till the weight reached constant before weighing. For samples collected at the physiological maturity stage, biomasses and harvest indices were calculated based on the measured dry matter accumulation values. SPAD values were measured with a chlorophyll meter (SPAD-502). In the V12 stage, the top fully unrolled leaves were measured. At R1, ear leaves were measured. Measurements were taken at a spot slightly deviant from the center of the leaves. Fifteen consecutive plants were measured in each plot.

2.7. Grain Yield. The total weight of the harvested maize grains in each plot was measured (total weight). Then, 3 random samples $(>1 \mathrm{~kg})$ were collected and weighed (gross weight). Impurities from these samples were discarded before the samples were weighed again (net weight). Impurity ratio was calculated: (gross weight-net weight) $\div$ gross weight.

3 random grain samples (100 kernels) were collected and weighed (wet weight). Then, grains were dried at $75^{\circ} \mathrm{C}$ till weight became constant before weighing (dry weight). The grain water content was calculated as (wet weight-dry weight $) \div$ net weight. The yield assuming a $14 \%$ water content was calculated as total weight $\times(1-$ impurity ratio $) \times(1-$ water content $) \div(1-14 \%)$.

2.8. Statistical Analysis. Data were organized with Microsoft Excel 2016. The data-processing system of SPSS statistics 8.0 software was used for analysis of variance. Analysis of variance (ANOVA) was followed by LSD tests at $P=0.05$ where appropriate. The least significant difference was adopted for the multiple comparisons in the analysis of variance of experimental treatment, and the significance level was 0.05. The LSD algorithm between different levels of different varieties and straw application is $\mathrm{LSD}_{0.05}=t_{0.05(d f)} \sqrt{\mathrm{MS}_{e} / \mathrm{ar}}$, where $t_{0.05(d f)}$ is the critical $t$-value of factor degree freedom under the $F$ test, $M S_{\mathrm{e}}$ is the error mean square, $a$ is the factor level number, and $r$ is the experimental treatment repetition times. The LSD algorithm of variety $\times$ straw application interaction is $\operatorname{LSD}_{0.05}=t_{0.05\left(d f_{e}\right)} \sqrt{2 \mathrm{MS}_{e} / r}$, where $d f_{\mathrm{e}}$ is the test error degree freedom.

\section{Results}

3.1. Yield and Harvest Index. The maize yield in each season was significantly affected by the straw application methods (Table 2). After the first straw application (from the rape plant harvest, 1 CNSA), the maize yields using the SDBP and SSBRT were higher than that using the SMMT by $26.8 \%$ and $17.7 \%$, respectively. However, after three seasons of straw application (rape, maize, and rape, 3 CNSA), the yields and biomasses using the SDBP, SSBRT, and SMMT were not significantly different $(P>0.05)$. Furthermore, compared to the first maize harvest, with the increase in rounds of mechanical harvesting and straw application, the yields with the SDBP and SSBRT were reduced by $16.7 \%$ and $12.7 \%$, respectively, whereas the yield using the SMMT was increased by $5.4 \%$. The increase in yield was mainly a result of the increase in biomass, i.e., the harvest indices were barely changed. The yield (average of 2017 and 2018 harvests) of latematuring cultivar BY9 was significantly higher than the earlymaturing cultivar JY99 (8.4\% and 7.7\%, respectively), mainly due to the higher biomasses and harvest indices of BY9.

3.2. Dry Matter Accumulation before Silking, Leaf Area Index, and Leaf Chlorophyll Content. Our results indicate that straw application methods strongly influenced dry matter 
TABLE 2: Maize yields and harvest indices under different practices of crop straw application.

\begin{tabular}{|c|c|c|c|c|c|c|}
\hline \multirow[t]{2}{*}{ CNSA } & \multicolumn{2}{|c|}{ Treatments } & Kernel yield (t/ha) & Biomass $(\mathrm{t} / \mathrm{ha})$ & Harvest index (\%) & Theoretical yield $(\mathrm{t} / \mathrm{ha})$ \\
\hline & \multirow{3}{*}{ Straw returns } & SDBP & $11.46 \pm 0.50 \mathrm{a}$ & $21.12 \pm 0.86 a$ & $52.96 \pm 0.68 \mathrm{a}$ & $12.76 \pm 0.61 \mathrm{a}$ \\
\hline \multirow{10}{*}{1} & & SSBRT & $10.64 \pm 0.47 b$ & $20.07 \pm 0.82 b$ & $53.65 \pm 1.43 a$ & $12.30 \pm 0.62 \mathrm{a}$ \\
\hline & & SMMT & $9.04 \pm 0.27 c$ & $18.11 \pm 0.74 \mathrm{c}$ & $54.31 \pm 1.02 \mathrm{a}$ & $11.22 \pm 0.56 b$ \\
\hline & \multirow{2}{*}{ Cultivars } & BY9 & $10.80 \pm 0.43 a$ & $20.56 \pm 0.87 \mathrm{a}$ & $54.72 \pm 1.12 \mathrm{a}$ & $12.81 \pm 0.66 \mathrm{a}$ \\
\hline & & JY99 & $9.96 \pm 0.39 b$ & $18.97 \pm 0.74 \mathrm{a}$ & $52.55 \pm 0.96 b$ & $11.37 \pm 0.53 b$ \\
\hline & \multirow{6}{*}{ Interaction } & BY9×SDBP & $11.53 \pm 0.56 \mathrm{a}$ & $21.58 \pm 0.87 a$ & $53.03 \pm 0.95 b c$ & $13.05 \pm 0.65 a$ \\
\hline & & BY9×SSBRT & $11.16 \pm 0.49 \mathrm{a}$ & $21.47 \pm 0.87 \mathrm{a}$ & $54.72 \pm 1.64 \mathrm{ab}$ & $13.40 \pm 0.76 \mathrm{a}$ \\
\hline & & BY9×SMMT & $9.72 \pm 0.25 b$ & $18.62 \pm 0.87 b c$ & $56.41 \pm 0.77 \mathrm{a}$ & $11.97 \pm 0.57 b c$ \\
\hline & & JY99×SDBP & $11.39 \pm 0.43 \mathrm{a}$ & $20.66 \pm 0.85 \mathrm{ab}$ & $52.89 \pm 0.40 \mathrm{bc}$ & $12.46 \pm 0.56 \mathrm{ab}$ \\
\hline & & JY99×SSBRT & $10.12 \pm 0.44 b$ & $18.67 \pm 0.76 b c$ & $52.57 \pm 1.21 c$ & $11.19 \pm 0.47 c$ \\
\hline & & JY99×SMMT & $8.36 \pm 0.29 c$ & $17.59 \pm 0.60 c$ & $52.20 \pm 1.27 \mathrm{c}$ & $10.47 \pm 0.55 c$ \\
\hline \multirow{11}{*}{3} & \multirow{3}{*}{ Straw returns } & SDBP & $9.55 \pm 0.29 a$ & $17.38 \pm 0.56 b$ & $54.11 \pm 1.28 \mathrm{a}$ & $10.74 \pm 0.39 b$ \\
\hline & & SSBRT & $9.29 \pm 0.35 \mathrm{a}$ & $16.79 \pm 0.72 b$ & $52.64 \pm 1.24 b$ & $10.09 \pm 0.60 c$ \\
\hline & & SMMT & $9.53 \pm 0.28 \mathrm{a}$ & $18.50 \pm 0.60 \mathrm{a}$ & $54.06 \pm 1.08 \mathrm{a}$ & $11.43 \pm 0.31 \mathrm{a}$ \\
\hline & \multirow{2}{*}{ Cultivars } & BY9 & $9.80 \pm 0.32 \mathrm{a}$ & $18.58 \pm 0.66 a$ & $55.41 \pm 1.25 a$ & $11.74 \pm 0.34 a$ \\
\hline & & JY99 & $9.10 \pm 0.28 b$ & $16.53 \pm 0.59 b$ & $51.79 \pm 1.14 b$ & $9.76 \pm 0.52 b$ \\
\hline & \multirow{6}{*}{ Interaction } & BY9×SDBP & $9.83 \pm 0.30 \mathrm{ab}$ & $18.25 \pm 0.50 b$ & $55.78 \pm 1.17 \mathrm{a}$ & $11.60 \pm 0.20 \mathrm{~b}$ \\
\hline & & BY9×SSBRT & $9.52 \pm 0.36 \mathrm{ab}$ & $17.47 \pm 0.78 b c$ & $54.59 \pm 1.28 \mathrm{a}$ & $10.87 \pm 0.63 b c$ \\
\hline & & BY $9 \times$ SMMT & $10.06 \pm 0.30 \mathrm{a}$ & $20.03 \pm 0.71 \mathrm{a}$ & $55.85 \pm 1.31 \mathrm{a}$ & $12.75 \pm 0.20 \mathrm{a}$ \\
\hline & & JY99×SDBP & $9.26 \pm 0.27 b c$ & $16.50 \pm 0.61 b c$ & $52.44 \pm 1.39 \mathrm{ab}$ & $9.87 \pm 0.58 \mathrm{~d}$ \\
\hline & & JY99×SSBRT & $9.05 \pm 0.33 c$ & $16.11 \pm 0.66 c$ & $50.68 \pm 1.20 \mathrm{~b}$ & $9.31 \pm 0.56 \mathrm{~d}$ \\
\hline & & JY99×SMMT & $9.00 \pm 0.25 c$ & $16.97 \pm 0.49 b c$ & $52.26 \pm 0.84 \mathrm{ab}$ & $10.11 \pm 0.42 \mathrm{~cd}$ \\
\hline
\end{tabular}

Groups labeled with different letters were significantly different $(P<0.05)$. The \pm sign is followed by the standard deviation. CNSA: cumulative number of straw returns.

accumulation before silking, leaf area index, and SPAD value (Table 3). After the first straw application, dry matter accumulation, leaf area index, and SPAD during V12 and R1 stages were significantly higher while using the SDBP than with SSBRT and SMMT, whereas after three consecutive straw applications, the SPAD value during the V12 stage and all three index values during the R1 stage were higher with SMMT. Furthermore, the three index values had a trend of reduction after three rounds of straw application with the SDBP and SSBRT, whereas for the SMMT, these numbers either increased or did not significantly change.

By comparing between the two cultivars, we found that straw application methods only affected SPAD values during the first season, whereas dry matter accumulation before silking and leaf area index were not significantly affected. Considering BY9 had a higher yield, we deduce that the dry matter accumulation after silking, compared to before silking, contributes more to the high yield of the late-maturing cultivar.

3.3. Volume and Distribution of the Root System. Figure 2 illustrates the root volume and distribution in each straw application method (average of the two cultivars). We found that, after one straw application, the SDBP and SSBRT methods showed higher average root volume in $0-60 \mathrm{~cm}$ depth range compared with the SMMT. In contrast, after three consecutive straw applications, the root volumes using the SDBP and SSBRT were not notably higher than using the SSMT. Particularly, the average root volume of the $0-40$ depth range with the SDBP was less than that using the SMMT by $29.6 \%$ at V12 and $7.5 \%$ at R1, after three consecutive straw applications.
In addition, we found that even after one round of straw application, the root volume in the $40-60 \mathrm{~cm}$ soil layer was not significantly different among the SMMT, SDBP, and SSBRT methods. As the root volume at deeper soil layers is positively correlated with yield, these data suggest that the immediate increase of root volumes with the SDBP and SSBRT may not have a strong benefit on the increase of yield. By comparing root volumes between one straw application and three straw applications, we found that in the R1 stage, $0-60 \mathrm{~cm}$ root volume with the SMMT was increased by $18.2 \%$, whereas that using SDBP was decreased by $28.0 \%$ and that by SSBRT was not significantly changed. These results suggest that the SMMT may have a delayed but long-term advantage in enhancing maize root volume.

3.4. Soil Penetration Resistance. Figure 3 illustrates soil penetration resistance at different depths during V12 and R1 stages with different straw application time periods. By comparing SDBP and SMMT, we found that soil penetration resistance with the SDBP was lower than that with SMMT at $0-30 \mathrm{~cm}$ range by an average of $32.8 \%$ (on average between 1 CNSA and 3 CNSA; the same below). However, soil penetration resistance was higher with the SDBP at $40-60 \mathrm{~cm}$ range by over $60.0 \%$. We also compared SSBRT and SMMT, and we found that while soil penetration resistance at $0-20 \mathrm{~cm}$ was not significantly different, the SSBRT method had a $24.8 \%$ higher soil penetration resistance than SMMT method at $20-60 \mathrm{~cm}$. Furthermore, we also found that the deep-layer soil penetration resistance $(50-60 \mathrm{~cm})$ increased after three straw applications in both the SSBRT $(791.9 \mathrm{KPa})$ and SDBP $(427.3 \mathrm{KPa})$ methods. 
TABLE 3: Dry matter accumulation, leaf area index, and SPAD value of maize under different practices of crop straw application.

\begin{tabular}{|c|c|c|c|c|c|c|c|c|}
\hline \multirow[b]{2}{*}{ CNSA } & \multirow{2}{*}{\multicolumn{2}{|c|}{ Treatments }} & \multicolumn{3}{|c|}{ Maize ear initiation stage (V12) } & \multicolumn{3}{|c|}{ Silking stage (R1) } \\
\hline & & & $\begin{array}{c}\text { Dry matter } \\
\text { weight (t/ha) }\end{array}$ & $\begin{array}{l}\text { Leaf area index } \\
(\mathrm{m} / \mathrm{m})\end{array}$ & $\begin{array}{c}\text { Leaf SPAD } \\
\text { values }\end{array}$ & $\begin{array}{c}\text { Dry matter } \\
\text { weight }(\mathrm{t} / \mathrm{ha})\end{array}$ & $\begin{array}{l}\text { Leaf area index } \\
(\mathrm{m} / \mathrm{m})\end{array}$ & $\begin{array}{c}\text { Leaf SPAD } \\
\text { values }\end{array}$ \\
\hline \multirow{11}{*}{1} & \multirow{3}{*}{$\begin{array}{l}\text { Straw } \\
\text { returns }\end{array}$} & SDBP & $0.39 \pm 0.04 a$ & $4.28 \pm 0.14 \mathrm{a}$ & $51.88 \pm 2.11 \mathrm{a}$ & $9.67 \pm 0.33 a$ & $5.19 \pm 0.18 \mathrm{a}$ & $56.40 \pm 0.83 a$ \\
\hline & & SSBRT & $0.26 \pm 0.02 b$ & $3.15 \pm 0.11 b$ & $47.37 \pm 1.26 b$ & $6.71 \pm 0.23 b$ & $4.37 \pm 0.13 b$ & $53.15 \pm 1.28 b$ \\
\hline & & SMMT & $0.25 \pm 0.01 b$ & $3.12 \pm 0.18 b$ & $47.53 \pm 1.12 b$ & $6.34 \pm 0.21 c$ & $4.29 \pm 0.18 b$ & $47.38 \pm 1.10 \mathrm{c}$ \\
\hline & \multirow{2}{*}{ Cultivars } & BY9 & $0.29 \pm 0.02 \mathrm{a}$ & $3.42 \pm 0.11 \mathrm{a}$ & $50.05 \pm 1.96 \mathrm{a}$ & $7.33 \pm 0.25 a$ & $4.58 \pm 0.17 \mathrm{a}$ & $51.51 \pm 1.12 b$ \\
\hline & & JY99 & $0.30 \pm 0.02 \mathrm{a}$ & $3.61 \pm 0.18 \mathrm{a}$ & $47.79 \pm 1.03 b$ & $7.80 \pm 0.27 \mathrm{a}$ & $4.64 \pm 0.15 a$ & $53.11 \pm 1.01 \mathrm{a}$ \\
\hline & \multirow{6}{*}{ Interaction } & BY9×SDBP & $0.35 \pm 0.03 b$ & $3.92 \pm 0.09 b$ & $53.43 \pm 2.01 \mathrm{a}$ & $9.57 \pm 0.30 \mathrm{a}$ & $5.25 \pm 0.16 \mathrm{a}$ & $55.73 \pm 0.75 \mathrm{ab}$ \\
\hline & & BY9×SSBRT & $0.26 \pm 0.02 c$ & $3.14 \pm 0.07 c$ & $49.39 \pm 2.16 b$ & $6.37 \pm 0.24 \mathrm{~cd}$ & $4.17 \pm 0.15 c$ & $52.47 \pm 1.48 c$ \\
\hline & & BY $9 \times$ SMMT & $0.27 \pm 0.01 \mathrm{c}$ & $3.21 \pm 0.16 \mathrm{c}$ & $47.34 \pm 1.70 \mathrm{bc}$ & $6.06 \pm 0.20 \mathrm{~d}$ & $4.33 \pm 0.20 \mathrm{bc}$ & $46.33 \pm 1.14 \mathrm{~d}$ \\
\hline & & JY99×SDBP & $0.42 \pm 0.04 \mathrm{a}$ & $4.64 \pm 0.19 a$ & $50.32 \pm 2.20 \mathrm{ab}$ & $9.76 \pm 0.36 \mathrm{a}$ & $5.12 \pm 0.20 \mathrm{a}$ & $57.07 \pm 0.91 \mathrm{a}$ \\
\hline & & JY99×SSBRT & $0.26 \pm 0.01 c$ & $3.15 \pm 0.15 c$ & $45.35 \pm 0.35 c$ & $7.04 \pm 0.23 b$ & $4.57 \pm 0.10 b$ & $53.83 \pm 1.07 \mathrm{bc}$ \\
\hline & & JY99×SMMT & $0.23 \pm 0.02 c$ & $3.03 \pm 0.20 c$ & $47.71 \pm 0.54 b c$ & $6.61 \pm 0.22 b c$ & $4.24 \pm 0.15 c$ & $48.43 \pm 1.05 \mathrm{~d}$ \\
\hline \multirow{11}{*}{3} & \multirow{3}{*}{$\begin{array}{l}\text { Straw } \\
\text { returns }\end{array}$} & SDBP & $0.17 \pm 0.01 \mathrm{a}$ & $2.53 \pm 0.15 \mathrm{a}$ & $42.78 \pm 1.00 \mathrm{~b}$ & $5.12 \pm 0.18 \mathrm{ab}$ & $4.42 \pm 0.20 \mathrm{~b}$ & $53.43 \pm 1.07 b$ \\
\hline & & SSBRT & $0.18 \pm 0.01 \mathrm{a}$ & $2.56 \pm 0.15 a$ & $44.27 \pm 0.87 \mathrm{ab}$ & $4.80 \pm 0.17 b$ & $4.24 \pm 0.17 c$ & $53.67 \pm 1.04 \mathrm{ab}$ \\
\hline & & SMMT & $0.17 \pm 0.01 \mathrm{a}$ & $2.45 \pm 0.11 \mathrm{a}$ & $45.95 \pm 1.10 \mathrm{a}$ & $5.30 \pm 0.12 \mathrm{a}$ & $4.61 \pm 0.19 \mathrm{a}$ & $54.65 \pm 0.83 a$ \\
\hline & \multirow{2}{*}{ Cultivars } & BY9 & $0.18 \pm 0.01 \mathrm{a}$ & $2.60 \pm 0.11 \mathrm{a}$ & $44.63 \pm 0.95 \mathrm{a}$ & $5.20 \pm 0.17 \mathrm{a}$ & $4.49 \pm 0.18 \mathrm{a}$ & $52.94 \pm 0.87 b$ \\
\hline & & JY99 & $0.16 \pm 0.01 \mathrm{a}$ & $2.43 \pm 0.16 b$ & $44.03 \pm 1.03 \mathrm{a}$ & $4.94 \pm 0.13 a$ & $4.35 \pm 0.18 a$ & $54.89 \pm 1.09 \mathrm{a}$ \\
\hline & \multirow{6}{*}{ Interaction } & BY9×SDBP & $0.19 \pm 0.01 \mathrm{a}$ & $2.86 \pm 0.13 a$ & $43.33 \pm 0.74 \mathrm{~cd}$ & $5.53 \pm 0.20 \mathrm{a}$ & $4.76 \pm 0.22 \mathrm{a}$ & $52.13 \pm 0.67 d$ \\
\hline & & BY $9 \times$ SSBRT & $0.17 \pm 0.01 b c$ & $2.45 \pm 0.12 b c$ & $44.33 \pm 0.92 b c$ & $4.65 \pm 0.15 c$ & $4.12 \pm 0.17 \mathrm{~cd}$ & $53.10 \pm 1.23 \mathrm{~cd}$ \\
\hline & & BY9×SMMT & $0.17 \pm 0.01 b c$ & $2.48 \pm 0.08 b c$ & $46.23 \pm 1.19 \mathrm{a}$ & $5.41 \pm 0.17 \mathrm{a}$ & $4.60 \pm 0.16 \mathrm{ab}$ & $53.60 \pm 0.71 b c$ \\
\hline & & JY99×SDBP & $0.14 \pm 0.01 d$ & $2.20 \pm 0.16 c$ & $42.23 \pm 1.26 \mathrm{~d}$ & $4.70 \pm 0.15 c$ & $4.07 \pm 0.17 \mathrm{~d}$ & $54.73 \pm 1.46 a b$ \\
\hline & & JY99×SSBRT & $0.18 \pm 0.00 \mathrm{ab}$ & $2.66 \pm 0.18 \mathrm{ab}$ & $44.20 \pm 0.82 b c$ & $4.95 \pm 0.18 b c$ & $4.36 \pm 0.17 b c$ & $54.23 \pm 0.85 \mathrm{ab}$ \\
\hline & & JY99×SMMT & $0.16 \pm 0.01 c$ & $2.42 \pm 0.14 \mathrm{bc}$ & $45.67 \pm 1.01 \mathrm{ab}$ & $5.18 \pm 0.07 \mathrm{ab}$ & $4.62 \pm 0.21 \mathrm{a}$ & $55.70 \pm 0.95 a$ \\
\hline
\end{tabular}

Groups labeled with different letters were significantly different $(P<0.05)$. The \pm sign is followed by the standard deviation. CNSA: cumulative number of straw returns.

Together, these results suggest that, although SDBP and SSBRT methods can effectively decrease soil penetration resistance in the shallow and medium soil layers, they can also increase the deep-layer soil penetration resistance. In contrast, SMMT cannot effectively decrease soil penetration resistance in the shallow layer, but it will not have a serious adverse impact on the deeper soil structure.

3.5. Soil Water Content. We found that the straw application methods significantly affected the soil water content, as shown in Figure 4. During the V12 stage (averaged between 1 CNSA and 3 CNSA; the same below), the SMMT method produced higher water content in the $0-30 \mathrm{~cm}$ soil layer than SDBP and SSBRT methods (by $15.2 \%$ and $18.0 \%$, respectively). Similar differences were observed in the $30-60 \mathrm{~cm}$ layer as well (11.3\% and 7.3\%, respectively). Importantly, in the superficial soil layer $(0-10 \mathrm{~cm})$, which is essential for maize germination, the SMMT still produced the highest water content, followed by SDBP (21.3\%) and SSBRT (19.0\%). During the R1 stage, the water content by the SMMT remained significantly higher than that by the SDBP (by $19.4 \%$ in the $0-30 \mathrm{~cm}$ layer and $6.9 \%$ in the $30-60 \mathrm{~cm}$ layer), while not significantly different from that by SSBRT.

3.6. Alkaline-Hydrolyzed Nitrogen Content. Figure 5 shows that straw application methods strongly impacted the AH-N content in the soil. In the V12 stage, the SMMT showed significantly more AH-N content in the $0-20 \mathrm{~cm}$ and $40-60 \mathrm{~cm}$ layers, compared with SDBP and SSBRT $(15.9 \%$ and $22.7 \%$ for $0-20 \mathrm{~cm}$ and $7.9 \%$ and $48.6 \%$ for $40-60 \mathrm{~cm}$, respectively, calculated with the averages between $1 \mathrm{CNSA}$ and 3 CNSA). In comparison, the SDBP and the SSBRT only showed higher content in the $20-40 \mathrm{~cm}$ layer $(21.5 \%$ and $16.7 \%$ higher than SMMT, respectively). During the R1 stage, in the $0-20 \mathrm{~cm}$ layer, AH-N content by the SMMT was significantly higher than that by the SDBP method (by 9.7\%), but it was not significantly different from that by the SSBRT; in the $20-40 \mathrm{~cm}$ layer, AH-N content with the SMMT was higher than that with the SSBRT but lower than with SDBP (by $12.8 \%$ and $5.5 \%$, respectively); in the $40-60 \mathrm{~cm}$ layer, AH-N content with the SMMT was significantly higher than with SDBP and SSBRT (by $73.8 \%$ and $71.9 \%$, respectively).

In addition, by comparing the data from one and three straw applications, we found that during V12, AH-N content with the SMMT in the $0-20 \mathrm{~cm}$ and $40-60 \mathrm{~cm}$ layers increased by $3.1 \%$ and $16.9 \%$, respectively, and the number decreased in the $20-40 \mathrm{~cm}$ layer by $12.9 \%$, but the overall $(0-60 \mathrm{~cm})$ AH-N content increased by $2.6 \%$. These results demonstrate that SMMT is overall advantageous in the continued improvement of AH-N content, particularly in the deep soil layers.

\section{Discussion}

The soil tillage and straw burial depth during straw application are determinants affecting soil tilth and maize grain yield [31]. Previous studies have demonstrated that compared with straw mulching with minimum tillage, straw deep burial with plowing and straw shallow burial with rotary tillage can improve the soil structure and root growth 

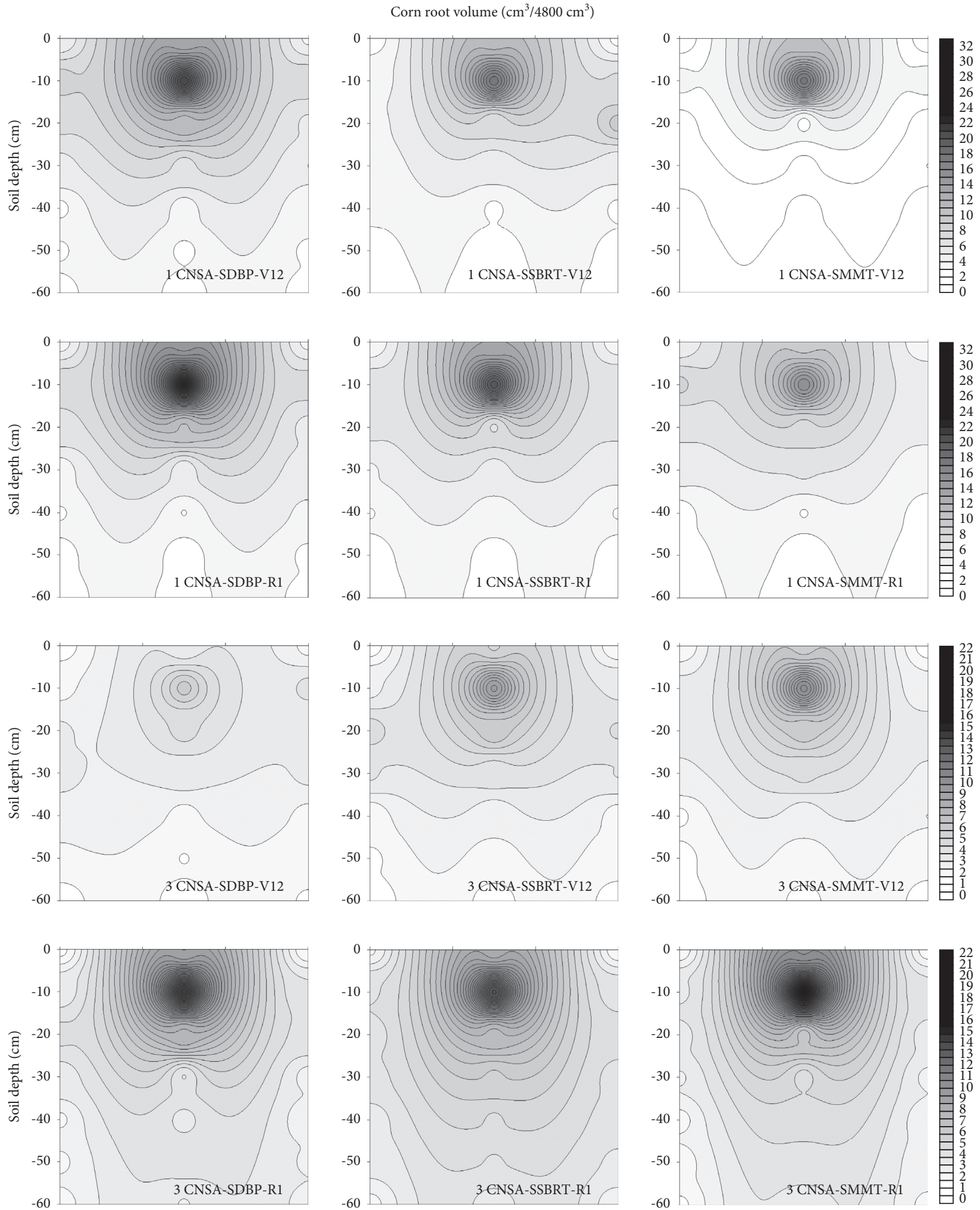

FIgURE 2: Maize root distribution under different practices of crop straw application.

environment, reduce the soil bulk density of the $0-20 \mathrm{~cm}$ arable layer, and increase the permeability and water retention performance of the soil, which promote root expansion and improve the capacity of roots to absorb water and nutrients [32]. Straw application with plowing tillage can restrict the horizontal water flow, promote straw decomposition, and increase soil moisture content and accumulation of available nutrients, thereby increasing the utilization of nitrogen fertilizer and maize grain yield [33]. In addition, the maize grain yield is higher with straw deep 

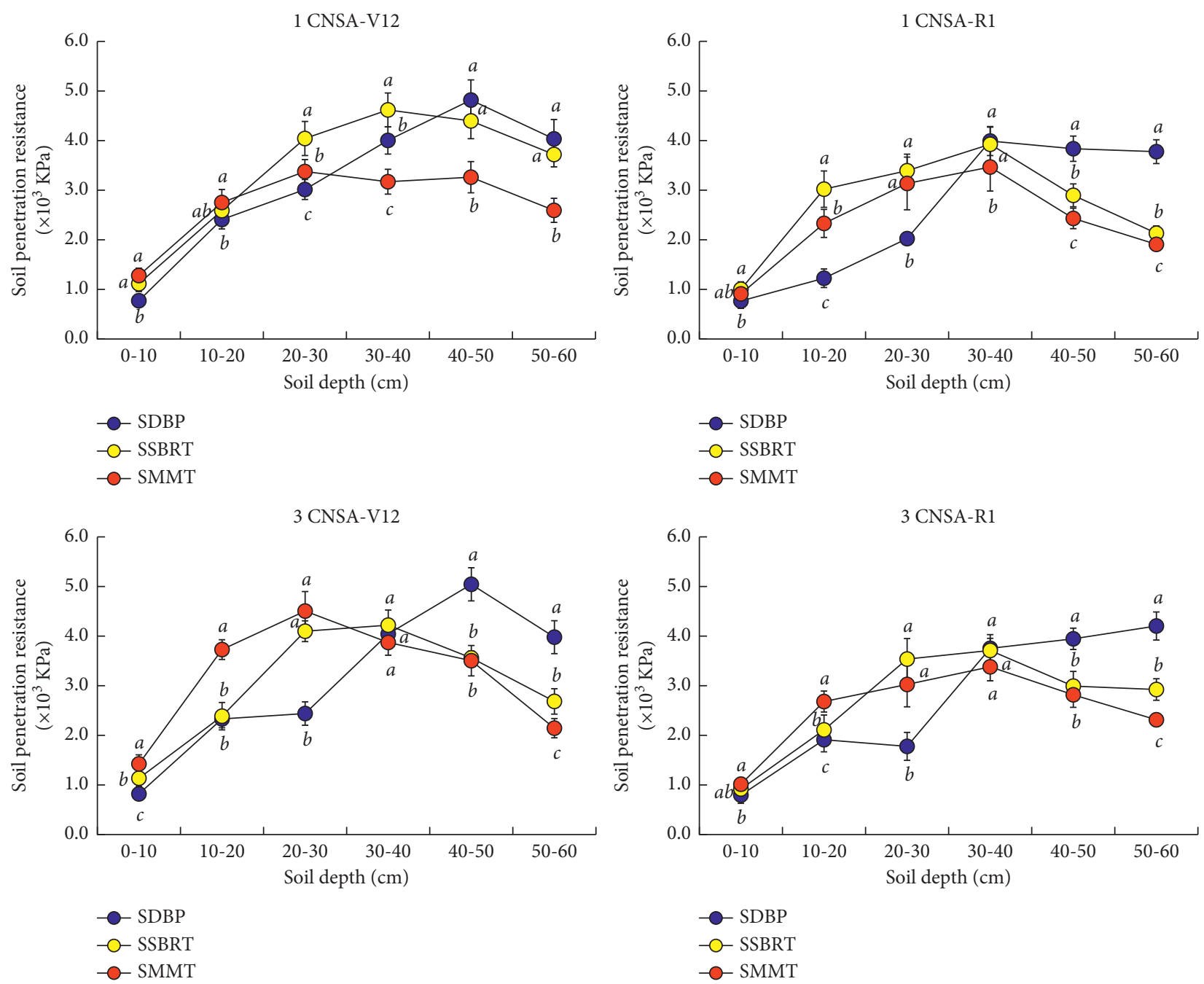

FIGURE 3: Soil penetration resistance in the maize-growing season under different practices of crop straw application.

burial with plowing compared to that with straw shallow burial [34].

However, soil macroaggregates are easily broken to form microaggregates or sand-to-clay-sized particles due to the strong disturbance of the arable layer by plowing or rotary tillage $[35,36]$, resulting in a decrease in the organic carbon content [37], which affects the growth and development of maize root systems [38]. Previous studies have indicated that compared with conventional soil rotary tillage, straw mulching with minimum tillage can provide a suitable soil environment for crop growth. This method can significantly increase the soil organic carbon [39-42] and moisture contents [43] and enhance the activities of urease, dehydrogenase, alkaline phosphatase, and other enzymes [44], which ultimately increases maize kernel weight [45] and grain yield $[39,40]$. Compared with continuous straw application with plowing tillage, the straw mulching with minimum tillage method can significantly increase the content and mean mass diameter of water-stable aggregates in the $20-50 \mathrm{~cm}$ soil layer, which effectively reduces the damage of soil aggregate structure and increases the water storage capacity of the $0-200 \mathrm{~cm}$ soil layer. The crop grain yield and water use efficiency by this method were increased by $15.1 \%$ and $27.5 \%$, respectively, compared with continuous straw application with plowing tillage [46]. Some studies also implied that the crop grain yield by straw mulching with conventional tillage is higher than that by straw mulching with minimum tillage; however, the operability and economic benefits of the latter are greater than those of the former $[47,48]$.

Our results show that compared with straw mulching with minimum tillage, straw deep burial with plowing and straw shallow burial with rotary tillage methods can reduce the density of surface soil layers and increase the root system volume after the first straw application, which plays a leading role in increasing the maize grain yield. However, after consecutive rounds of mechanical harvesting and straw application, soil density of $0-40 \mathrm{~cm}$ layer was significantly increased with straw deep burial with plowing and straw shallow burial with rotary tillage. The interaction between soil tillage and straw application is the main factor affecting soil porosity. Specifically, the mixture of straws and soils increased the soil porosity [49] and reduced moisture content of the $0-30 \mathrm{~cm}$ soil layer and AH-N content of the $0-20$ and 


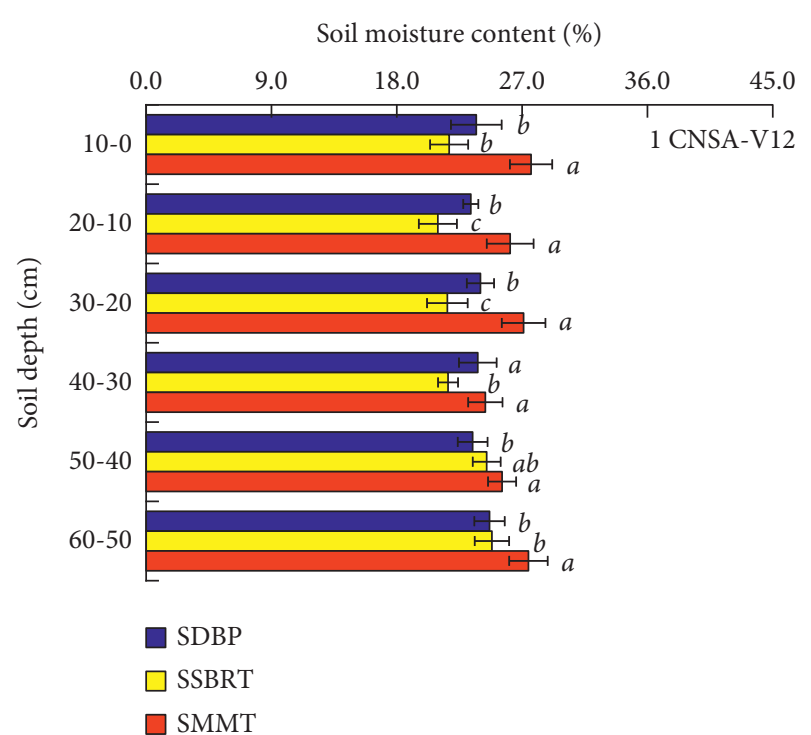

Soil moisture content (\%)

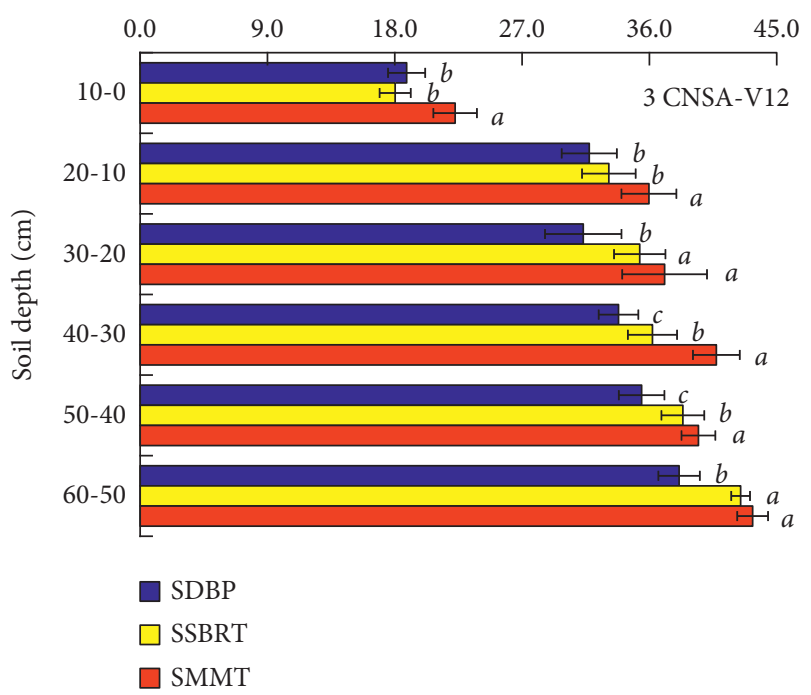

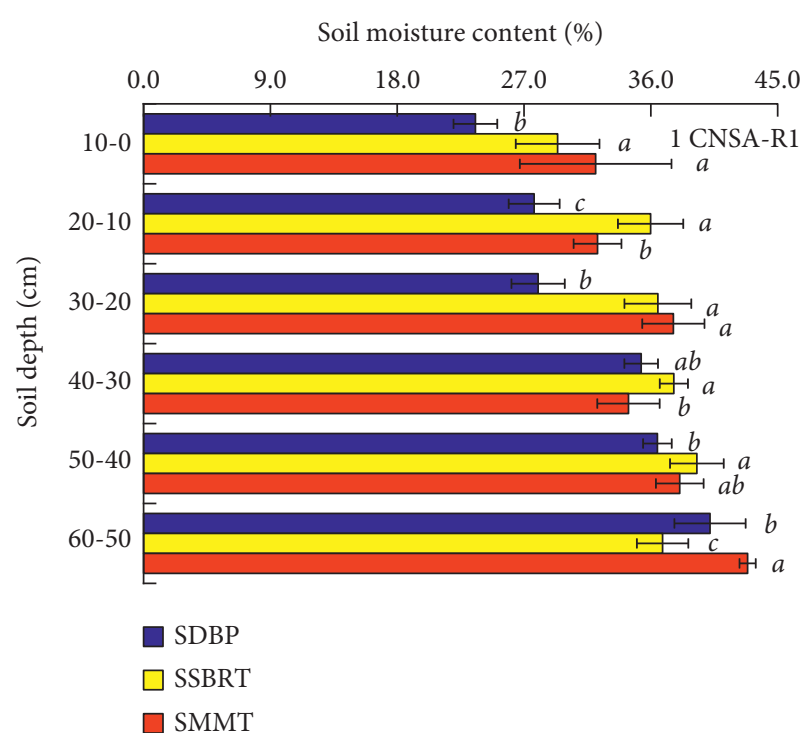

Soil moisture content (\%)

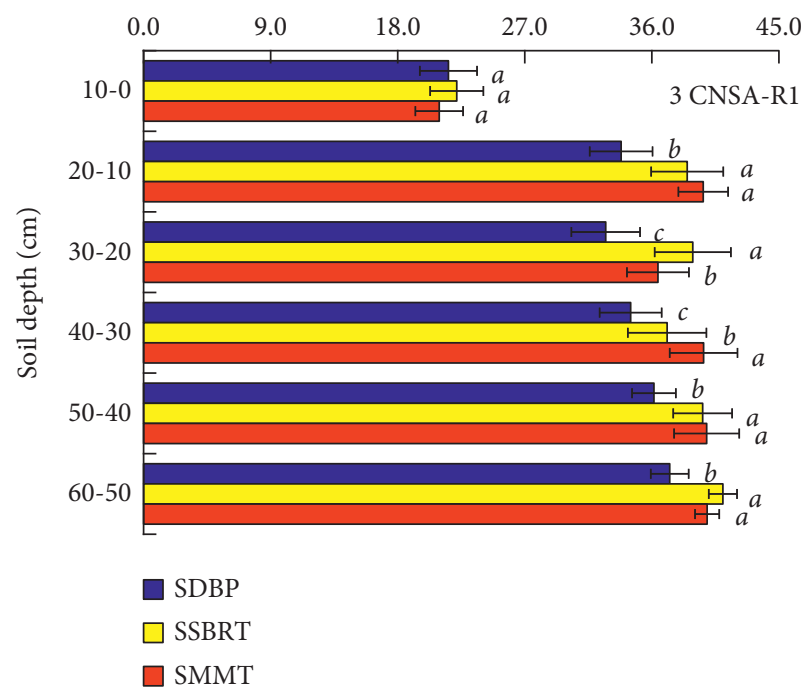

FIGURE 4: Soil water content in the maize-growing season under different practices of crop straw application.

$40-60 \mathrm{~cm}$ soil layers at the early stage of maize growth. As a result, the growth and development of the maize root system are suppressed, leading to a significant lower maize grain yield compared with that of the previous season. In the Yunnan Plateau in Southwest China, considering frequent seasonal droughts during maize planting and poor soil fertility of the arable layer, the employment of straw mulching with minimum tillage method can increase soil moisture and nutrient contents, which is of great significance in improving the maize emergence rate and grain yield.
Nevertheless, there are some issues associated with the straw mulching with minimum tillage during maize seeding process. Either in mechanical ditching with manual seeding or mechanical seeding, the removal of straw covers by ditching a shovel or seed meter will increase water loss in the soil, which, in turn, leads to a decrease in maize emergence rate $[50,51]$. Therefore, the utilization of appropriate equipment for seeding and increase in the seeding depth are required to provide a suitable soil environment for seed germination and emergence. 

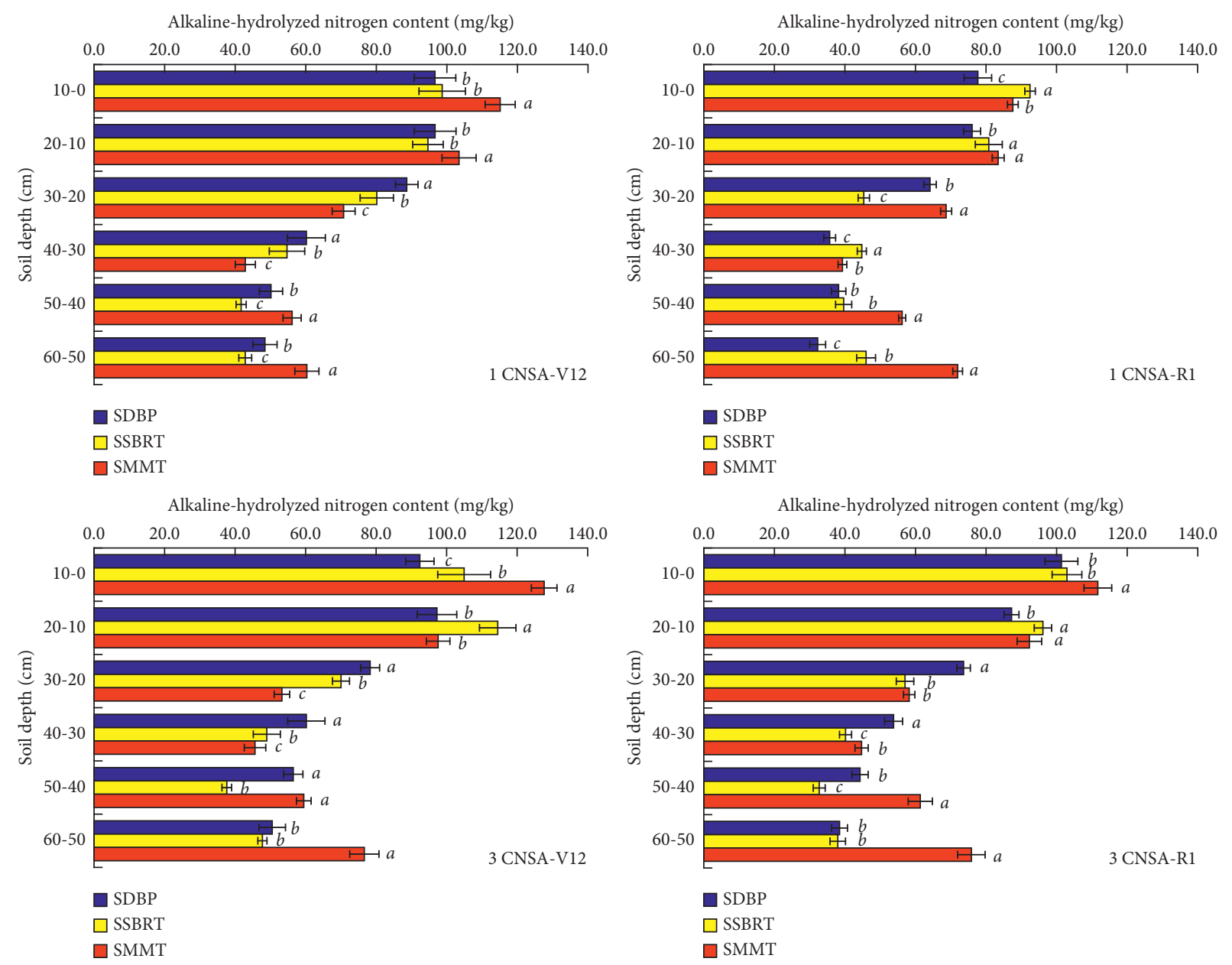

FiguRE 5: Alkaline-hydrolyzed nitrogen content in the maize-growing season under different practices of crop straw application.

\section{Conclusion}

During mechanical harvesting, the maize grain yield significantly decreases with repeated straw applications using straw deep burial with plowing and straw shallow burial with rotary tillage methods. In contrast, the straw mulching with minimum tillage method can increase the soil moisture content of the arable layer, increase the alkaline-hydrolyzed nitrogen content of shallow or deep soil layers, and promote the growth and development of the maize root system, thus increasing the maize grain yield.

\section{Data Availability}

The experimental data used to support the findings of this study are available from the corresponding author upon request.

\section{Conflicts of Interest}

The authors declare that they have no conflicts of interest regarding the present study.

\section{Acknowledgments}

This work was supported by the National Key Research and Development Program of China (2016YFD03003) and Young and Middle-Aged Academic Leaders Reserve Talent Project of Honghe University (2016HB0402).

\section{References}

[1] I. A. Dahri, A. A. Tagar, J. Adamowski, N. Leghari, A. R. Shah, and S. A. Soomro, "Influence of straw incorporation-toplanting interval on soil physical properties and maize performance," International Agrophysics, vol. 32, no. 3, pp. 341-347, 2018.

[2] H. Zhao, A. G. Shar, S. Li et al., "Effect of straw return mode on soil aggregation and aggregate carbon content in an annual maize-wheat double cropping system," Soil and Tillage Research, vol. 175, pp. 178-186, 2018.

[3] X. Hao, X. Han, S. Wang, and L.-J. Li, "Dynamics and composition of soil organic carbon in response to 15 years of straw return in a Mollisol," Soil and Tillage Research, vol. 215, Article ID 105221, 2022.

[4] X. Wang, Z. Jia, L. Liang et al., "Changes in soil characteristics and maize yield under straw returning system in dryland farming," Field Crops Research, vol. 218, pp. 11-17, 2018. 
[5] M. T. Rahman, Z. C. Guo, Z. B. Zhang, H. Zhou, and $\mathrm{X}$. H. Peng, "Wetting and drying cycles improving aggregation and associated $\mathrm{C}$ stabilization differently after straw or biochar incorporated into a Vertisol," Soil and Tillage Research, vol. 175, pp. 28-36, 2018.

[6] D. Yu, Z. Wen, X. Li, X. Song, H. Wu, and P. Yang, "Effects of straw return on bacterial communities in a wheat-maize rotation system in the North China Plain," PLoS One, vol. 13, no. 6, Article ID e0198087, 2018.

[7] L. Yan, Z. Zhang, Y. Chen, Q. Gao, W. Lu, and A. M. Abdelrahman, "Effect of water and temperature on ammonia volatilization of maize straw returning," Toxicological and Environmental Chemistry, vol. 98, no. 5-6, pp. 638-647, 2016.

[8] S. W. Mei, S. Wang, and X. W. Yang, "Straw returning and nitrogen application on winter wheat quality and yield under wheat-maize multiple cropping system," Ekoloji, vol. 28, pp. 2183-2192, 2019.

[9] A. S. Sidhu and H. S. Sur, "Effect of Incorporation of legume straw on soil properties and crop yield in a maize-wheat sequence," Tropical Agriculture, vol. 70, pp. 226-229, 1993.

[10] J. Bakht, M. Shafi, M. T. Jan, and Z. Shah, "Influence of crop residue management, cropping system and $\mathrm{N}$ fertilizer on soil $\mathrm{N}$ and $\mathrm{C}$ dynamics and sustainable wheat (Triticum aestivum L.) production," Soil and Tillage Research, vol. 104, no. 2, pp. 233-240, 2009.

[11] W. Fan, J. Wu, J. Li, and J. Hu, "Comparative effects of different maize straw returning modes on soil humus composition and humic acid structural characteristics in Northeast China," Chemistry and Ecology, vol. 34, no. 4, pp. 355-370, 2018.

[12] J. Paul, A. K. Choudhary, V. K. Suri, A. K. Sharma, V. Kumar, and Shobhna, "Bioresource nutrient recycling and its relationship with biofertility indicators of soil health and nutrient dynamics in rice-wheat cropping system," Communications in Soil Science and Plant Analysis, vol. 45, no. 7, pp. 912-924, 2014.

[13] Y. Fan, J. Gao, J. Sun et al., "Effects of straw returning and potassium fertilizer application on root characteristics and yield of spring maize in China inner Mongolia," Agronomy Journal, vol. 113, no. 5, pp. 4369-4385, 2021.

[14] T. Pandiaraj, S. Selvaraj, and N. Ramu, "Effects of crop residue management and nitrogen fertilizer on soil nitrogen and carbon content and productivity of wheat (Triticum aestivum L.) in two cropping systems," Journal of Agricultural Science and Technology A, vol. 17, pp. 249-260, 2015.

[15] C. Jiang and W. Yu, "Maize production and field $\mathrm{CO} 2$ emission under different straw return rates in Northeast China," Plant Soil and Environment, vol. 65, no. 4, pp. 198-204, 2019.

[16] L. Bechini, C. Costamagna, L. Zavattaro, C. Grignani, J. Bijttebier, and G. Ruysschaert, "Barriers and drivers towards the incorporation of crop residue in the soil. Analysis of Italian farmers' opinion with the theory of planned behaviour," Italian Journal of Agronomy, vol. 10, no. 4, pp. 178-184, 2015.

[17] C. B. Henriksen, J. Rasmussen, and C. Søgaard, "Ridging in autumn as an alternative to mouldboard ploughing in a humid-temperate region," Soil and Tillage Research, vol. 85, no. 1-2, pp. 27-37, 2006.

[18] K. Manevski, C. D. Børgesen, X. Li et al., "Optimising crop production and nitrate leaching in China: measured and simulated effects of straw incorporation and nitrogen fertilisation," European Journal of Agronomy, vol. 80, pp. 32-44, 2016.

[19] J. M. Carefoot, H. H. Janzen, and C. W. Lindwall, "Crop residue management for irrigated cereals on the semi-arid Canadian prairies," Soil and Tillage Research, vol. 32, no. 1, pp. 1-20, 1994.

[20] X. Zhang, N. Sun, L. Wu, M. Xu, I. J. Bingham, and Z. Li, "Effects of enhancing soil organic carbon sequestration in the topsoil by fertilization on crop productivity and stability: evidence from long-term experiments with wheat-maize cropping systems in China," The Science of the Total Environment, vol. 562, pp. 247-259, 2016.

[21] K. Saffih-Hdadi and B. Mary, "Modeling consequences of straw residues export on soil organic carbon," Soil Biology and Biochemistry, vol. 40, no. 3, pp. 594-607, 2008.

[22] M. A. Bughio, P. Wang, F. Meng, Q. Chen, J. Li, and T. A. Shaikh, "Neoformation of pedogenic carbonate and conservation of lithogenic carbonate by farming practices and their contribution to carbon sequestration in soil," Journal of Plant Nutrition and Soil Science, vol. 180, no. 4, pp. 454-463, 2017.

[23] Y. Li, D. Song, P. Dang, L. Wei, X. Qin, and K. H. M. Siddique, "Combined ditch buried straw return technology in a ridgefurrow plastic film mulch system: implications for crop yield and soil organic matter dynamics," Soil and Tillage Research, vol. 199, Article ID 104596, 2020.

[24] P. Tian, P. Sui, H. Lian et al., "Maize straw returning approaches affected straw decomposition and soil carbon and nitrogen storage in Northeast China," Agronomy, vol. 9, no. 12 , p. $818,2019$.

[25] S. Sharma, A. Rangger, M. von Lützow, and H. Insam, "Functional diversity of soil bacterial communities increases after maize litter amendment," European Journal of Soil Biology, vol. 34, no. 2, pp. 53-60, 1998.

[26] X. Xia, P. Zhang, L. He et al., "Effects of tillage managements and maize straw returning on soil microbiome using $16 \mathrm{~S}$ rDNA sequencing," Journal of Integrative Plant Biology, vol. 61, no. 6, pp. 765-777, 2019.

[27] D. Zhou, Y. Su, Y. Ning et al., "Estimation of the effects of maize straw return on soil carbon and nutrients using response surface methodology," Pedosphere, vol. 28, no. 3, pp. 411-421, 2018.

[28] J. L. Zhao, Y. Lu, H. L. Tian, H. L. Jia, and M. Z. Guo, "Effects of straw returning and residue cleaner on the soil moisture content, soil temperature, and maize emergence rate in China's three major maize producing areas," Sustainability, vol. 11, no. 20, p. 5796, 2019.

[29] P. Sharma, V. Abrol, G. R. M. Sankar, and B. Singh, "Influence of tillage practices and mulching options on productivity, economics and soil physical properties of maize (Zea mays)wheat (Triticum aestivum) system," Indian Journal of Agricultural Sciences, vol. 79, pp. 865-870, 2009.

[30] H. Ram, Y. Singh, K. S. Saini, D. S. Kler, J. Timsina, and E. J. Humphreys, "Agronomic and economic evaluation of permanent raised beds, no tillage and straw mulching for an irrigated maize-wheat system in Northwest India," Experimental Agriculture, vol. 48, no. 1, pp. 21-38, 2012.

[31] M. Bahrani, M. Raufat, and H. Ghadiri, "Influence of wheat residue management on irrigated corn grain production in a reduced tillage system," Soil and Tillage Research, vol. 94, no. 2, pp. 305-309, 2007.

[32] K. L. Ding and M. J. Hann, "Effects of soil management on soil properties and crop yield," Transactions of the CSAE, vol. 16, pp. 28-31, 2000. 
[33] E. Nafi, H. Webber, I. Danso, J. B. Naab, M. Frei, and T. Gaiser, "Soil tillage, residue management and site interactions affecting nitrogen use efficiency in maize and cotton in the Sudan Savanna of Africa," Field Crops Research, vol. 244, Article ID 107629, 2019.

[34] B. Prochazkova, J. Malek, and J. Dovrtel, "Effect of different straw management practices on yields of continuous spring barley," Rostlinna Vyroba, vol. 48, pp. 27-32, 2002.

[35] E. T. Elliott, "Aggregate structure and carbon, nitrogen, and phosphorus in native and cultivated soils," Soil Science Society of America Journal, vol. 50, no. 3, pp. 627-633, 1986.

[36] G. P. S. Sodhi, V. Beri, and D. K. Benbi, "Soil aggregation and distribution of carbon and nitrogen in different fractions under long-term application of compost in rice-wheat system," Soil and Tillage Research, vol. 103, no. 2, pp. 412-418, 2009.

[37] D. A. Angers, A. N'dayegamiye, and D. Côté, “Tillage-induced differences in organic matter of particle-size fractions and microbial biomass," Soil Science Society of America Journal, vol. 57, no. 2, pp. 512-516, 1993.

[38] J. M. Tisdall and J. M. Oades, "Organic matter and waterstable aggregates in soils," Journal of Soil Science, vol. 33, no. 2, pp. 141-163, 1982.

[39] K. S. Gangwar, K. K. Singh, S. K. Sharma, and O. K. Tomar, "Alternative tillage and crop residue management in wheat after rice in sandy loam soils of Indo-Gangetic plains," Soil and Tillage Research, vol. 88, no. 1-2, pp. 242-252, 2006.

[40] J. Xu, H. Han, T. Ning, Z. Li, and R. Lal, "Long-term effects of tillage and straw management on soil organic carbon, crop yield, and yield stability in a wheat-maize system," Field Crops Research, vol. 233, pp. 33-40, 2019.

[41] R. Saha and P. K. Ghosh, "Soil organic carbon stock, moisture availability and crop yield as influenced by residue management and tillage practices in maize-mustard cropping system under hill agro-ecosystem," National Academy Science Letters, vol. 36, no. 5, pp. 461-468, 2013.

[42] C. E. P. Lima, M. R. Fontenelle, N. R. Madeira et al., "Compartimentos de carbono orgânico em Latossolo cultivado com hortaliças sob diferentes manejos," Pesquisa Agropecuária Brasileira, vol. 51, no. 4, pp. 378-387, 2016.

[43] M. Mtyobile, L. Muzangwa, and P. N. S. Mnkeni, "Tillage and crop rotation effects on soil carbon and selected soil physical properties in a Haplic Cambisol in Eastern Cape, South Africa," Soil and Water Research, vol. 15, pp. 47-54, 2020.

[44] D. A. Bossio, J. A. Fleck, K. M. Scow, and R. Fujii, “Alteration of soil microbial communities and water quality in restored wetlands," Soil Biology and Biochemistry, vol. 38, no. 6, pp. 1223-1233, 2006.

[45] F. A. Chandio, Y. M. Li, S. A. Shaikh et al., "Effect of straw incorporation by tillage implements combination on physicochemical properties of soil and maize productivity in field condition. Fresen," Fresenius Environmental Bulletin, vol. 27, pp. 7527-7535, 2018.

[46] D. Liu, X. Zhang, J. Li, and X. D. Wang, "Effects of different tillage patterns on soil properties, maize yield and water use efficiency in Weibei Highland, China," Journal of Applied Ecology, vol. 29, pp. 573-582, 2018.

[47] Z. Li, X. Lai, Q. Yang, X. Yang, S. Cui, and Y. Shen, "In search of long-term sustainable tillage and straw mulching practices for a maize-winter wheat-soybean rotation system in the Loess Plateau of China," Field Crops Research, vol. 217, pp. 199-210, 2018.

[48] X. Lu and X. Lu, "Tillage and crop residue effects on the energy consumption, input-output costs and greenhouse gas emissions of maize crops," Nutrient Cycling in Agroecosystems, vol. 108, no. 3, pp. 323-337, 2017.

[49] N. Tangyuan, H. Bin, J. Nianyuan, T. Shenzhong, and L. Zengjia, "Effects of conservation tillage on soil porosity in maize-wheat cropping system," Plant Soil and Environment, vol. 55, no. 8, pp. 327-333, 2009.

[50] E. M. Brandelero, A. G. D. Araújo, and R. Ralisch, "Coverage mobilization in the sowing line and its influence on temperature and water content and on maize emergence," Engenharia Agrícola, vol. 35, no. 1, pp. 98-108, 2015.

[51] M.-P. Hiel, S. Barbieux, J. Pierreux et al., "Impact of crop residue management on crop production and soil chemistry after seven years of crop rotation in temperate climate, loamy soils," PeerJ, vol. 6, p. e4836, 2018. 